\title{
Q Achonoledgments
}

People have commented, upon learning of the focus of my book, that I must have come from a home full of strong women. This is correct, but the women (and men) I grew up with were responsible for much more than a research topic. Two homesteading women from Wyoming-the "Equality State," which was the first in the world to give women the right to vote (1869) and home to more of the nation's firsts for women: first female justice of peace and bailiff (1870), first female jury (1870), first female statewide official (1894), first all-female town government (1920), and first female governor (1924) - left an indelible imprint on their posterity. Granny Cookie's brimming determination (a condition she describes as being "filled with piss and vinegar") and Grandma Vivian's fiery advocacy continue to fill those around them with light and strength. A true cowgirl my mother, Gail, never ceases getting back on that horse, real or metaphorical. It is her unwavering faith in the never-ending abilities and potential of her family that is the engine of our progress.

My father, Wayne, besides being a loving and involved father wisely surveyed the fault-line of historical change that ran through our family farm. His foresight at a moment of great seismic shift and his insistence that I "seek wisdom and learning" (for example by taking high school French and calculus instead of animal husbandry and ag shop) gave me alternatives, including academia. For this I am grateful, though there were nostalgic moments on the long road to tenure where rural poverty seemed a welcome alternative to the academic kind. My older yet 
close siblings-Jeff, Angela, and Crystal-set personal and professional examples to which I still aspire.

At Hawaii and Berkeley, friends and mentors worked patiently with me as I refined my topic. They include Barbara Andaya, Leonard Andaya, Jeff Belnap, Nelleke van Deusen-Scholl, Jeff Hadler, Carla Hesse, Gene Irschick, Alan Karras, Ninik Lunde, Tom Metcalf, Nancy Peluso, Tony Reid, Johan Snapper, Randy Starn, Jean Taylor, Sylvia Tiwon, Jan de Vries, and Peter Zinoman.

The help, friendship, and "local knowledge" of individuals too numerous to mention made the years spent abroad memorable and enjoyable. In the Netherlands many contributed directly to my research. These include Leonard Blusse, Peter Boomgaard, Peter Christiaans, Wim van den Doel, Femme Gaastra, Frances Gouda, Pieter Koenders, Theo van der Meer, Henk Niemeijer, Remco Raben, Gerritt Knaap, and support personnel at ARA, CBG, KB, UA, UL, KITLV, and TANAP. In Indonesia and Malaysia, those involved in helping and shaping me and my topic include Jim Collins, Darus, Mason Hoadley, Sophie Muzwar, Shamsul, Uri Tadmore, Thee Kian Wie, and others at ANRI, ATMA, IKIP, LIPI, and UKM.

I incurred many debts along the way, human and otherwise, but the financial burden would have been far greater if not for the generous awards of many funding agencies that made this project possible. They include Ehrman Chair Fellowship, Regents Fellowship of the University of California, Humanities Research Grant, UC Grant-in-Aid, Netherlands-America Foundation Nordholt-Leiden History Grant, J. William Fulbright Full Grants to the Netherlands and Malaysia, UC Berkeley Department of History Traveling Fellowship, Foreign Language Area Studies fellowships in Bahasa Indonesian and Afrikaans, Consortium of Teaching Indonesian-Malay (COTIM) Fellowship, Foreign and Domestic Travel Awards from NIU's Center for Southeast Asian Studies, Robbins Fellowship at UC Berkeley's Boalt School of Law, and NIU's Summer Research and Artistry Award.

Friends and colleagues made the journey worthwhile. I thank Kathy Anderson, Taylor Atkins, Maitrii Aung-Thwin, Jim Collins, Chris DeRosa, Sean Farrell, Jeff Hadler, Trude Jacobsen, Andrew Jainchill, Tina Jamaluddin, John Roosa, Dar Rudnyckyj, Priya Satia, Jim Schmidt, Shamsul, Eric Tagliacozzo, Carol Tan, my colleagues at the Center for Southeast Asian 
Studies at NIU, and many students for reading over different incarnations of this manuscript and giving freely of their time and insights. Thanks to the students at the San Quentin State Prison College Program who were brave enough to sign up for my "Colonial Literature and History of Indonesia" course and heard so much about my research. I am eternally grateful to Jim Collins at NIU's Center for Southeast Asian Studies, Alex Schwartz at NIU Press, and several anonymous readers for spearheading the book's publication. Jim Schmidt deserves special attention as one of the most gifted academic mentors (and flatpickin' guitarists) around. Having three kids-Taylor, Spencer, and Ethan-has been as crazy as everyone thinks, but their enthusiasm and my fear of not putting food in their mouths has both fed me and made me hungry. 
